\title{
ANALISIS FAKTOR-FAKTOR PENENTU KEBERHASILAN USAHA BALE HIDROPONIK DAN DAMPAKNYA BAGI MASYARAKAT SEKITAR
}

\author{
Tinti Asmara *1), Lasmono Tri Sunaryanto 1) \\ 1) Program Studi Agribisnis, Fakultas Pertanian dan Bisnis, Universitas Kristen Satya Wacana, \\ Salatiga,Indonesia \\ *) E-mail Penulis Korespondensi: 522017043@student.uksw.edu
}

\begin{abstract}
ABSTRAK
Tujuan penelitian ini: 1) menganalisis faktor-faktor penentu keberhasilan usaha Bale Hidroponik dan dampaknya bagi masyarakat sekitar dan 2) mengidentifikasi proses keberhasilan usaha dalam menjual produknya. Penelitian dilakukan di Bale Hidroponik Salatiga, Jawa Tengah. Penelitian berpotensi sebagai penggerak pengembangan agribisnis dibidang tanaman hortikultura yang dikembangkan menggunakan teknik budidaya secara konsep hidroponik. Teknik analisis data menggunakan model kualitatif interaktif dengan tahapan analisis mulai dari pengumpulan data, reduksi data, penyajian data dan penarikan kesimpulan. Uji kredibilitas data dilakukan dengan cara triangulasi sumber dan triangulasi teknik. Hasil penelitian menunjukkan bahwa faktor penentu keberhasilan usaha Bale Hidroponik Salatiga meliputi faktor sumber daya manusia, keuangan, organisasi, manajemen usaha, distribusi dan pemerintah. Dampak usaha bagi masyarakat sekitar selain dapat berbelanja sayur langsung ke green house Bale Hidroponik dan dapat melihat secara langsung proses produksi yang dilakukan, masyarakat sekitar juga dapat belajar membuat instalasi hidroponik dengan bantuan pemilik. Bale Hidroponik juga mempekerjakan beberapa masyarakat sekitar di green house milik Bale Hidroponik dan masyarakat sekitar dapat belajar mengenai pertanian secara hidroponik dan cara memasarkannya. Kinerja pengelola Bale Hidroponik Salatiga dapat terus ditingkatkan dalam mengembangkan bisnisnya terutama peningkatan terhadap kinerja karyawan.
\end{abstract}

Kata Kunci: Bale Hidroponik; Keberhasilan Usaha; Dampak Bisnis; Penjualan; Salatiga.

\section{PENDAHULUAN}

Sektor pertanian merupakan sektor yang mempunyai peranan strategis dalam struktur pembangunan perekonomian nasional. Pertanian merupakan salah satu sektor yang sangat dominan dalam pendapatan masyarakat di Indonesia karena mayoritas penduduk Indonesia bekerja sebagai petani. Sektor pertanian mempengaruhi perkembangan dan pertumbuhan perekonomian bangsa (Masykur, 2011). Menurut Badan Pusat Statistik (2015) produksi sayuran meningkat tiap tahunnya. Pada tahun 2013 produksi sayuran yaitu 11.558 .449 ton dan pada tahun 2014 meningkat sebesar 11.918.571 ton. Hal ini menunjukkan harus adanya peningkatan produksi sayuran untuk mengimbangi peningkatan kebutuhan komoditas sayuran sebagai akibat peningkatan jumlah penduduk di Indonesia. Pertanian lahan sempit yang saat ini diterapkan adalah budidaya hidroponik. Teknologi hidroponik ini termasuk teknologi baru, di Indonesia sendiri mulai dikenal sejak tahun 80 -an. Teknologi hidroponik mulai mendapat perhatian dan semakin berkembang, khususnya untuk menghasilkan produk tanaman hortikultura dan florikultura. 
Perkembangan metode bercocok hidroponik cukup bagus. Dengan ketersediaan lahan yang semakin sempit, masyarakat mulai tertarik dengan hidroponik karena bertanam dengan sistem hidroponik bisa dilakukan dimana saja. Dengan hidroponik bertanam sayuran, buah ataupun bunga mulai di halaman rumah, di samping rumah ataupun lainnya (Anang Masduki, 2018). Penggunaan produk-produk berkualitas memberikan rasa nyaman bagi penggunanya. Pasar-pasar modern menjadi ciri khas tentang produk yang berkualitas tinggi, bukan lagi produk yang banyak namun produk yang bersih dan memiliki kontinuitas tinggi (Siwu, 2019). Salah satu produsen sayuran yang menggunakan teknologi hidroponik adalah Bale Hidroponik Salatiga. Bale Hidroponik Salatiga adalah suatu usaha yang bergerak di bidang agribisnis yaitu sebagai tempat produksi produk, pengolahan, pengemasan produk hingga pemasaran produk. Berbagai jenis sayur yang ditanam di Bale Hidroponik antara lain: sawi pagoda, selada, bayam, pacoy, seledri dan lainnya. Perkembangan usaha semakin dirasakan, yang awalnya belum memiliki label penjualan sendiri sekarang telah memiliki label sendiri, usaha ini semakin dikenal banyak orang.

Penelitian yang dilakukan oleh Della Adriani dan Lucyana (2020) tentang Faktorfaktor penentu keberhasilan usaha minuman tradisional menunjukkan hasil penelitian bahwa yang diperoleh adalah faktor yang menetukan adalah faktor internal dan eksternal yang meliputi organisasi, kegiatan karyawan serta lingkungan kerja. Penelitian yang dilakukan oleh Sulistyowati dan Lestari (2016) menunjukkan hasil pengaruh strategi bisnis terhadap kinerja usaha kecil dan menengah di wilayah kota Yogyakarta dengan korelasi yang kurang kuat dan faktor pengelolaan usaha yang kurang memadai.

Menurut Hendro (2011) terdapat faktor-faktor penentu keberhasilan usaha antara lain faktor sumber daya manusia, faktor keuangan, faktor organisasi, faktor pengelolaan usaha, faktor distribusi dan faktor dukungan pemerintah. Karakteristik yang didalamnya meliputi sumber daya manusia yang berkualitas, kepandaian dalam mengembangkan usaha, memiliki target dalam usaha, memiliki daya ingat yang baik dan kreatif dalam mengatasi segala kendala, daya pemimpin dan cara kepemimpinan yang berdedikasi tinggi atas usaha yang dijalankan. Penelitian ini bertujuan untuk menganalisis faktorfaktor penentu keberhasilan usaha Bale Hidroponik dan dampaknya bagi masyarakat sekitar, serta mengidentifikasi proses keberhasilan usaha Bale Hidroponik dalam menjual produknya.

\section{METODE}

Lokasi penelitian dilaksanakan di Bale Hidroponik Salatiga, Jawa Tengah. Waktu pelaksanaan pengumpulan data dilaksanakan selama dua bulan, yakni pada bulan Agustus sampai dengan Oktober 2020. Penelitian ini merupakan penelitian deskriptif kualitatif. Adapun yang dimaksud dengan deskriptif adalah metode dalam penelitian suatu objek, kondisi maupun pemikiran pada suatu peristiwa atau kejadian untuk masa yang sekarang (Maulana, 2016). Data kualitatif berlandaskan data hasil interview dimana memuat semua penjelasan yang diinginkan penulis. Untuk memahami serta mengikuti peristiwa yang terjadi diruang lingkup tempat penelitian, serta menilai sebab akibat yang ditimbulkan dari lingkungan sosial orang-orang setempat dan memperoleh penemuanpenemuan tak terduga sebelumnya (Sugiyono, 2019).

Dalam penelitian ini jenis data yang digunakan yakni data primer dan data sekunder. Teknik pada penentuan informan menggunakan metode purposive. Informasi kunci (key informant) penelitian ini adalah Aditya Yoga Sustika dan Gristhoper Allo Posende yakni pemilik usaha Bale Hidroponik, jumlah informasi kunci (key nformant) adalah dua orang. Sedangkan Informan (informant) penelitian ini adalah Maria pangestika, yakni salah satu karyawan Bale Hidroponik Salatiga, jumlah informan (informant) adalah satu orang. Teknik pengumpulan data yang digunakan dalam penelitian adalah observasi, wawancara, studi pustaka dan dokumentasi. Uji keabsahan data yang dipakai dalam penelitian ini adalah uji credibility. Uji credibility atau uji 
kredibilitas terhadap data penelitian yang telah diambil oleh peneliti agar hasil penelitian tidak diragukan. Dalam uji kredibilitas terdapat dua cara yang digunakan yaitu triangulasi sumber dan triangulasi teknik. Triangulasi sumber dilakukan untuk menguji kredibilitas data dengan cara mengecek data yang telah didapatkan melalui beberapa sumber. Data diperoleh setelah mewawancarai informan-informan tidak dirata-ratakan seperti dalam penelitian kuantitatif, tetapi dideskripsikan, dikategorikan, dan mengidentifikasi terhadap pandangan yang sama dan yang berbeda. Data yang sudah dianalisis oleh peneliti selanjutnya dimintakan kesepakatan (member check) dengan tiga sumber data tersebut. Selanjutnya, triangulasi teknik dilakukan untuk menguji kredibilitas data dengan mengecek data yang didapat dengan teknik yang berbeda. Sebagai contoh awal pengambilan data menggunakan wawancara, kemudian dicek dengan observasi atau dokumentasi. Apabila data yang didapatkan berbeda dengan data awal maka dilakukan diskusi lanjut bersama dengan narasumber yang bersangkutan untuk memastikan data yang dianggap benar (Sugiyono, 2019).

Dalam penelitian ini teknik analisis data yang digunakan adalah teknik analisis data kualitatif dengan model interaktif yang merupakan upaya yang berlanjut, yang berulang dan terus menerus (Miles dan Huberman, 2007). Metode analisis ini terdiri dari empat alur kegiatan yang terjadi secara bersamaan diantaranya terdiri dari:

1. Pengumpulan data

Pengumpulan data dilakukan dengan observasi ke lokasi penelitian, wawancara mendalam (indept interview) kepada informan kunci, dan berbagai kegiatan dokumentasi berdasarkan kategori yang sesuai dengan masalah yang akan diteliti kemudian lebih dikembangkan ketajaman data melalui pencarian data berikutnya.

2. Reduksi data

Reduksi data dilakukan dengan menggolongkan, mengarahkan, membuang data yang tidak perlu dan mengorganisasikan data dengan cara sedemikian rupa sehingga mendapatkan simpulan final yang dapat ditarik dan diverifikasi. Reduksi data dapat berlangsung secara terus menerus sepanjang penelitian belum berakhir. Hasil dari reduksi data bisa berupa ringkasan dari catatan lapangan, baik dari catatan awal, perluasan hingga penambahan catatan.

3. Penyajian data

Penyajian data dimaksudkan untuk menemukan pola-pola yang bermakna serta memberikan keterangan kemungkinan adanya penarikan kesimpulan serta memberikan tindakan. Sajian data bisa berupa kalimat, gambar atau skema, jaringan kerja dan tabel sebagai narasinya.

4. Penarikan kesimpulan

Kesimpulan diverifikasi selama penelitian berlangsung. Kesimpulan ditarik selama penelitian menyusun, pencatatan, pola-pola, pernyataan, konfigurasi, arahan sebab akibat dan berbagai proposisi.

\section{HASIL DAN PEMBAHASAN}

\section{Profil Bale Hidroponik Salatiga}

Bale Hidroponik Salatiga merupakan suatu usaha yang dikelola secara perorangan yang didirikan oleh Aditya Yoga Sustika, S.P, dan Gristhoper Allo Posende, Kedua orang tersebut adalah alumni UKSW. Sebelum ada namanya Bale Hidroponik, usaha ini dulunya bernama Suka Sayur yang dirintis pada tahun 2014. Akhirnya pada tahun 2017 usaha tersebut sudah menunjukkan titik terang dan mulai berkembang. Bale Hidroponik mempunyai 1 green house yang beralamat di jalan Mutiara No,35 Kelurahan Bugel, Kecamatan Sidorejo, Kota Salatiga - 50714, Jawa Tengah - Indonesia. Adapun jam operasional Bale Hidroponik adalah senin - sabtu mulai pukul 08.00-16.00 WIB. Bale Hidroponik saat ini bermitra dengan beberapa swalayan dan resto yang ada di Salatiga dan Semarang. Saat ini karyawan yang dimiliki Bale Hidroponik berjumlah 8 orang. Bale Hidroponik juga menerima kunjungan home tour dan praktik kerja lapangan (PKL) bagi 
siswa siswi tingkat menengah atas serta penelitian dibidang terkait. Selain itu pelayanan yang diberikan pihak Bale Hidroponik atau pemilik dan karyawan yakni ramah, harga sayur terjangkau dan fasilitas yang mendukung. Saat ini Bale Hidroponik memiliki 40 lebih jenis sayur yang berbeda yang siap dipasarkan kepada konsumen, di swalayan/supermarket dan restoran. Total mitra jual Bale Hidroponik saat ini ada 12 mitra termasuk resto. Saat ini produk sayur segar Bale Hidroponik juga dipasarkan melalui sosial media seperti Instagram, Whatsapp, Facebook, Youtube dan Tiktok.

\section{Karakteristik Narasumber}

Narasumber yang digunakan dalam penelitian ini berjumlah tiga orang yang terbagi atas dua orang sebagai pemilik usaha yang disebut informan kunci, dan satunya lagi sebagai karyawan yang disebut informan. Informan kunci adalah dua orang yang bernama Aditya Yoga S. dan Gristhoper Allo Posende yang merupakan pemilik Bale Hidroponik Salatiga, sedangkan yang menjadi informan adalah Maria Pangestika yakni karyawan Bale Hidroponik. Karakteristik narasumber yang ditinjau melalui wawancara diantaranya umur, jabatan, jenis kelamin alamat, pekerjaan serta pendidikan. Karakteristik tersebut dibutuhkan guna menunjang hasil penelitian peneliti.

\section{Faktor Penentu Keberhasilan Usaha}

\section{Faktor Sumber Daya Manusia (SDM)}

Pemilik Bale Hidroponik memiliki karakteristik yakni sumber daya manusia yang cukup. Hal ini dapat dilihat dari wawasan yang luas dari SDM yang dimiliki dan keinginan untuk berkembang, terdapat visi misi usaha maupun visi misi pribadi, sikap tidak mudah putus asa dan tidak mudah puas dengan pencapaian yang sekarang serta selalu memperbaiki manajemen pekerjaan. Dalam menjalankan sebuah bisnis sayur segar Bale Hidroponik tidak menganggap kompetitor sebagai pesaing, tetapi pemilik Bale Hidroponik lebih menganggap pesaing sebagai tempat kolaborasi dalam mengembangkan bisnis. Bahkan pesaing bisa menjadi rekan bisnis. Berdasarkan teori Hendro (2011), mengenai sumber daya manusia pemilik Bale Hidroponik memiliki karakteristik yakni sumber daya manusia yang cukup. Hal ini dapat dilihat dari wawasan yang luas dan ingin berkembang, terdapat visi misi usaha maupun visi misi pribadi, sikap tidak mudah putus asa dan tidak mudah puas dengan pencapaian yang sekarang serta selalu memperbaiki manajemen pekerjaan.

\section{Faktor Keuangan}

Kepengurusan keuangan dipegang langsung oleh pemilik Bale Hidroponik dengan bantuan satur orang tenaga administrasi keuangan. Ini dikarenakan mengurus keuangan diperlukan ketelitian sebab akan menimbulkan kendala di waktu mendatang. Dengan bantuan karyawan tenaga administrasi dapat meringankan pekerjaan pemilik dalam dalam mengatur pengeluaran dan pemasukan uang. mengenai faktor keuangan, pemilik Bale Hidroponik telah memiliki karakteristik wirausaha tersebut dengan mengatur keuangan dengan bijak. Meskipun terdapat kesalahan dalam mengelola keuangan tetapi pemilik Bale tetap meminimalkan kesalahan tersebut dengan bersikap tenang dan terus bekerja dengan baik dan mengatur karyawan agar tetap menjalankan tugas dan tanggung jawabnya masing-masing. Berdasarkan teori Hendro (2011), mengenai faktor keuangan pemilik Bale Hidroponik telah memiliki karakteristik wirausaha tersebut dengan mengatur keuangan dengan bijak. Seperti Pengendalian akan biaya dan anggaran perusahaan, modal kerja modal investasi, juga harga bermacam produk merupakan faktor keberlangsungan usaha. Dengan penanganan keuangan yang baik maka akan membantu pemilik mewujudkan usaha yang mandiri dan berkembang. 


\section{Faktor Organisasi}

Faktor organisasi menjadi penentu keberhasilan usaha karena Pemilik Bale Hidroponik memiliki karakteristik, dimana pemilik telah memenuhi beberapa indikator dalam pernyataan Hendro (2011) yang mempertimbangkan faktor organisasi yakni komunikasi yang baik antar teman maupun perusahaan, memiliki batasan-batasan pekerjaan, bekerja sesuai kemampuan, tidak mencampuri pekerjaan orang lain dan selalu menjalin hubungan yang baik antar sesama rekan kerja dan orang lain. Karakteristik inilah yang akan membantu pemilik untuk lebih mampu mengembangkan usahanya dan mampu bersaing dalam keadaan apapun di pasar. Sebagai seorang pemimpin dalam menjalankan usaha, pemilik selalu memiliki sikap percaya diri dalam memajukan usahanya, baik meningkatkan penjualan maupun memperbanyak pasar. Pemilik telah membuat produk sebaik mungkin yang membuat pelanggan maupun konsumen puas terhadap produk Bale Hidroponik. Pengontrolan produksi sayur terus dilakukan baik sayur yang berasal dari green house Bale Hidroponik sendiri maupun produk sayur dari mitra beli seperti petani sayur.

\section{Faktor Pengelolaan Usaha}

Sebagai seorang pemimpin dalam menjalankan usaha, pemilik selalu memiliki sikap percaya diri dalam memajukan usahanya, baik meningkatkan penjualan maupun memperbanyak pasar. Pemilik telah menghasilkan produk sebaik mungkin yang membuat pelanggan maupun konsumen puas terhadap produk Bale Hidroponik. Pengontrolan produksi sayur terus dilakukan baik sayur yang berasal dari green house Bale Hidroponik sendiri maupun produk sayur dari mitra beli seperti petani sayur. Dalam meningkatkan mutu produk sayur Bale Hidroponik, pemilik sering melakukan pengecekan produk ke toko mitra jual agar dapat mengetahui sejauh mana produk tersebut bertahan dan dapat bersaing dengan produk orang lain. Serta pemilik dapat mengetahui kekurangan dari produk Bale Hidroponik. Persediaan sayur segar selalu tersedia untuk mitra dan resto. Sayur diambil dari green house Bale Hidroponik dan supply dari petani yang berasal dari petani kopeng, Ampel dan Selo. Juga terdapat petani rumahan sebagai penyumbang sayur kepada Bale Hidroponik. Berdasarkan teori Hendro (2011) pemilik Bale Hidroponik Salaiga telah memenuhi kriteria tersebut. Hal ini dikarenakan pemilik telah memenuhi indikator-indikator teori Hendro (2011) yang meliputi pemilik telah pandai mengendalikan mutu produk, persediaan barang, tenaga kerja, distribusi barang yang normal, pengelolaan asset, organisasi yang tersusun rapi, sumber daya manusia yang memadai dan memiliki jadwal kerja yang jelas. Adanya dukungan pada diri sendiri dalam menjalankan usaha sehingga tugas dan pekerjaan dapat berjalan dengan baik.

\section{Faktor Distribusi}

Banyak manfaat yang diperoleh ketika memasarkan produknya melalui media sosial. Pemilik juga meyakini bahwa dengan teknik pemasaran produk melalui media sosial yang dijalankan dapat meningkatkan penjualan. Apalagi saat ini penjualan semakin meningkat meskipun terdampak kendala Covid-19 di masyarakat, sehingga konsumsi kebutuhan akan bahan makanan semakin meningkat salah satunya kebutuhan sayur mayur. Teknik pemasaran produk melalui media sosial yang dijalankan dapat meningkatkan penjualan. Saat ini pemilik juga baru memasarkan produknya secara online melalui media sosial yang ada seperti instagram, youtube, whatsapp, tiktok dan lainnya. Hal ini juga selaras dengan peranan media sosial yang dikemukakan oleh Meilinda (2018), secara tidak langsung proses kegiatan promosi dan pemasaran melalui media sosial dapat menghadapi banyaknya pesaing pasar. Pemilihan media sosial sebagai bentuk pemasaran yang tepat dan sangat terpadu agar dapat menghasilkan hasil yang diinginkan sehingga meningkatkan penjualan. Media sosial mampu memberikan dampak positif bagi Bale Hidroponik, dengan berbagai media sosial yang digunakan dalam memasarkan produk. Pemilik telah memberikan kemampuan terbaiknya dalam memimpin 
usaha maupun menaikan penjualan produk. Hal ini sejalan dengan pernyataan Hendro (2011), bahwa Seorang wirausaha harus memiliki kemampuan dalam memasarkan produk olahannya.

\section{Faktor Dukungan Pemerintah}

Bale Hidroponik telah memiliki izin usaha dari pihak kecamatan Sidorejo Kota Salatiga, Provinsi Jawa Tengah. Usaha ini telah memiliki pajak usaha yang mana pajak usaha tersebut selalu dijalankan dan di bayar tiap bulannya. Pajak usaha ini masih milik perorangan dan pajak usaha ini masih memakai nama salah satu pemilik Bale Hidroponik yakni Aditya Yoga S. Dalam menjalankan suatu usaha faktor pemerintah menjadi acuan utama, faktor ini berpengaruh kepada usaha karena memiliki beberapa ketentuan yang harus dipenuhi dan peraturan yang harus ditaati diantaranya: memiliki surat izin usaha, pajak usaha, memperhatikan situasi politik dan ekonomi, lingkungan sosial. Masyarakat sekitar sendiri menerima dengan baik adanya bangunan usaha ini, meskipun awalnya masyarakat sempat bingung atas usaha yang akan didirikan, akan tetapi seiring berjalankan waktu akhirnya masyarakat paham dengan apa yang dimaksud oleh pemilik dan ada inisiatif masyarakat untuk ikut serta membuat instalasi hidroponik. Berdasarkan teori Hendro (2011), mengenai faktor pemerintah, pemilik Bale Hidroponik telah memiliki karakteristik tersebut, hanya saja ada yang belum terpenuhi yakni izin usaha yang dari pemerintahan pusat, selebihnya pemilik telah memenuhi karakteristik tersebut.

\section{Dampak Usaha Bagi Masyarakat Sekitar}

Usaha yang dijalankan oleh pemilik Bale Hidroponik telah memberikan dampak positif terhadap masyarakat sekitar dimana masyarakat dapat melihat dan berbelanja sayur secara langsung di green house milik Bale Hidroponik. Selain itu masyarakat dapat melihat secara langsung proses produksi yang dilakukan, sehingga masyarakat dapat belajar membuat instalasi hidroponik dengan bantuan pemilik. Bale Hidroponik juga mempekerjakan beberapa masyarakat sekitar di green house milik Bale Hidroponik dan masyarakat sekitar dapat belajar mengenai pertanian secara hidroponik dan cara memasarkannya. Berdasarkan teori Suharno (2014), tentang dampak positif maka pemilik mempunyai karakteristik tersebut dengan berbuat baik, memberikan kesan kepada orang lain serta memberi bantuan kepada masyarakat sekitar. Dari karakteristik tersebut pemilik dapat terus menjalin hubungan baik dengan masyarakat sekitar untuk keberlanjutan usaha. Berdasarkan hasil penelitian ini, ditemukannya bahwa masyarakat sekitar jarang bahkan tidak pernah melakukan komplain kepada pemilik atas adanya usaha ini. Pemilik selalu menjaga keselarasan antar sesama. Dengan keadaan tersebut pemilik dapat terus berkarya dan mengembangkan usahanya.

\section{SIMPULAN}

Faktor-faktor penentu keberhasilan usaha Bale Hidroponik antara lain adalah faktor sumber daya manusia, faktor keuangan, faktor organisasi, faktor pengelolaan usaha, dan faktor pemerintah. Usaha Bale Hidroponik telah memiliki sumber daya manusia yang cukup dengan adanya karyawan tetap dan karyawan part time. Pengelolaan keuangan yang telah dilakukan dengan baik seperti pengendalian akan biaya dan anggaran usaha, modal kerja, modal investasi, juga penentuan harga bermacam produk merupakan faktor keberlangsungan usaha. Pemilik mampu mengembangkan usahanya sebaik mungkin sehingga dapat memperoleh karyawan tetap dan memiliki beberapa mitra di kota Salatiga maupun di luar kota Salatiga. Faktor dukungan pemerintah melalui izin usaha yang jelas dari pihak pemerintah setempat sehingga usaha ini layak untuk dijalankan dan dapat membantu perekonomian warga sekitar.

Dampak positif yang ditimbulkan dari usaha ini khususnya bagi masyarakat sekitar dimana masyarakat dapat berbelanja sayur langsung ke green house Bale Hidroponik 
dan dapat melihat secara langsung proses produksi yang dilakukan, masyarakat sekitar dapat belajar membuat instalasi hidroponik dengan bantuan pemilik, Bale Hidroponik juga mempekerjakan beberapa masyarakat sekitar di green house milik Bale Hidroponik dan masyarakat sekitar dapat belajar mengenai pertanian secara hidroponik dan cara memasarkannya.

Proses keberhasilan usaha Bale Hidroponik dalam menjual produknya dilakukan melalui media sosial seperti pada aplikasi instagram, facebook, whatsapp dan terdapat beberapa platform media sosial lainnya dalam melakukan promosi produk Bale Hidroponik antara lain melalui aplikasi youtube dan tiktok. Bale Hidroponik juga melayani pembelian langsung di tempat produksi dengan model pemesanan sayur seperti mengikuti $\mathrm{PO}$.

Faktor penentu keberhasilan usaha dan dampak positif yang ditimbulkan bagi masyarakat sekitar memiliki peran penting dalam pengembangan usaha kedepan, sehingga perlu dipertahankan dan ditingkatkan. Selain itu, pengelola usaha Bale Hidroponik Salatiga perlu memperhatikan kinerja karyawan, sehingga mampu dalam membangun usaha yang maju dan produktif.

\section{DAFTAR PUSTAKA}

Adriani, D dan Trimo, L. 2020. "Faktor-Faktor Penentu Keberhasilan Usaha Minuman Tradisional". Jurnal Ekonomi Pertanian dan Agribisnis (JEPA), 4(2), 323-334.

Badan Pusat Statistik. (2015). Kota Salatiga dalam Angka 2015. Salatiga: Badan Pusat Statistik Kota Salatiga.

Hendro, I. M. 2011. Dasar - Dasar Kewirausahaan. Jakarta: Erlangga.

Juliana V., Setiawan I., dan Bidayan E. (2018). Analisis Faktor-Faktor Yang Mempengaruhi Tingkat Keberhasilan Usaha Penjualan Buah-Buah Di Kecamatan Sungailiat Kabupaten Bangka. Jurnal Ekonomi Pertanian dan Agribisnis (JEPA), 2(5), 341-352.

Kristanto, Heru. (2010). Kewirausahaan Enterpreneurship: Pendekatan Manajemen dan Praktik. Yogyakarta: Graha IImu.

Masduki, Anang. (2018). "Hidroponik Sebagai Sarana Pemanfaatan Lahan Sempit Di Dusun Randubelang Bangunharjo Sewon Bantul". Jurnal Pemberdayaan, 1(2), 185192.

Masykur. (2011). Pengantar Kewirausahaan Kerangka Dasar. Yogyakarta: BPFE.

Maulana, A. (2016). "Penentuan Prioritas Strategi Pariwisata Dengan Menggunakan Metode Quantitative Strategic Planning Matrix". Jurnal Pengkajian Dan Pengembangan Teknologi Pertanian, 15(1), 67-79.

Meilinda, T. (2018). Peranan Media Sosial Instagram Sebagai Alat Promosi Dalam Meningkatkan Volume Penjualan Pada Restoran Sakurakita Palembang. Skripsi. Politeknik Negri Sriwijaya, Palembang. (Dipublikasikan).

Miles, M. B. dan A. Michael Hubermand. (2007). Analisis Data Kualitatif Buku Sumber Tenang Metode-Metode Baru, Terjemahan Tjetjep Rohendi Rohisi. Jakarta: Universitas Indonesia.

Pamungkas Rizki dan Magnadi Rizal Hari. (2015). Faktor-Faktor Penentu Keberhasilan Usaha Pada Pemegang Usaha Waralaba (Studi Kasus Pada Usaha Waralaba Makanan dan Minuman Lokal di Kota Semarang). Diponegoro Journal Of Management, 3(1), 1-14.

Siwu, H. F. D. (2019). "Strategi Pertumbuhan Dan Pembangunan Ekonomi Daerah". Jurnal Pembangunan Ekonomi Dan Keuangan Daerah, 19(3), 1-11. 
Sugiyono. (2019). Buku Metode Penelitian Kuantitatif Kualitatif dan $R$ \& $D$. Bandung: Alfabeta.

Suharno. (2014). Metode Penelitian Bisnis. Jakarta: Salemba Empat.

Sulistyowati, Eny dan Lestari, Nining Sofiati. (2016). Faktor-Faktor Penentu Keberhasilan Usaha Kecil dan Menengah (UKM) di Kota Yogyakarta. Jurnal Maksipreneur, 6(1), 24-36. 